\title{
Cross Pathogenicity of Gaeumannomyces graminis var. graminis from Bermudagrass, St. Augustinegrass, and Rice in Florida and Texas
}

\author{
L. E. Datnoff, Associate Professor of Plant Pathology, University of Florida-IFAS, Everglades Research and Edu- \\ cation Center, Belle Glade 33430; M. L. Elliott, Associate Professor of Plant Pathology, University of Florida- \\ IFAS, Ft. Lauderdale Research and Education Center, Ft. Lauderdale 33314; and J. P. Krausz, Extension Plant Pa- \\ thologist, Texas A \& M University, College Station 77843
}

\begin{abstract}
Datnoff, L. E., Elliott, M. L., and Krausz, J. P. 1997. Cross pathogenicity of Gaeumannomyces graminis var. graminis from bermudagrass, St. Augustinegrass, and rice in Florida and Texas. Plant Dis. 81:1127-1131.

Isolates of Gaeumannomyces graminis var. graminis were obtained from St. Augustinegrass, bermudagrass, and rice in Florida, and rice and St. Augustinegrass in Texas. In Florida, all seven isolates evaluated were cross pathogenic on each of the three grass hosts. Rice isolate FL173 caused significantly greater disease of the lower leaf sheath and root disease severity of rice compared with other isolates, whether from rice or both turfgrass species. The rice and both turfgrass isolates generally suppressed heights and shoot and root weights compared with the control. All isolates from either rice or both turfgrass species generally had root disease ratings significantly different from the control for either bermudagrass or St. Augustinegrass. However, rice isolate FL-173 and St. Augustinegrass isolate FL-104 were significantly more aggressive on St. Augustinegrass; whereas the maximum root disease rating of bermudagrass was only associated with bermudagrass isolate FL-19 and St. Augustinegrass isolate FL-104. In Texas, both the rice isolate TX-91-1 and the St. Augustinegrass isolate TX-10466-2 of G. graminis var. graminis were pathogenic on St. Augustinegrass, common bermudagrass, and rice. Both isolates caused similar disease severity on common bermudagrass and St. Augustinegrass, but isolate TX 10466-2 caused less severe disease symptoms on rice than did isolate TX-91-1. Overall, $G$. graminis var. graminis was most aggressive on the host from which it was originally isolated, such as rice or St. Augustine, but differences in host-plant reactions were not always statistically significant, especially with bermudagrass.
\end{abstract}

Crown (black) sheath rot, caused by Gaeumannomyces graminis (Sacc.) von Arx \& D. Olivier var. graminis, was identified for the first time in rice (Oryza sativa L.) grown in Florida in 1991 (3). Although it is usually considered a minor disease, epidemics have caused considerable yield and quality losses in rice in Texas (18). This pathogen also is the etiological agent of bermudagrass (Cynodon dactylon (L.) Pers. $\times$ transvaalensis Burtt-Davy) decline (4) and take-all root rot of St. Augustinegrass (Stenotaphrum secundatum (Walter) Kuntze) $(7,9,10)$.

St. Augustinegrass sod is grown on about 15,385 ha in the Everglades Agricultural Area (EAA) south of Lake Okeechobee in Florida. Rice is grown on about 8,906 ha in this same area in rotation with sugarcane and vegetables. In some areas, rice and sod fields can lie adjacent to

Corresponding author: L. E. Datnoff Email: LEDA@GNV.IFAS.UFL.EDU

Florida Agricultural Experiment Station, Journal Series No. R-05585.

Accepted for publication 17 June 1997.

Publication no. D-1997-0804-03R

(C) 1997 The American Phytopathological Society each other and even share the same irrigation system. Contiguous plantings of rice and sod also occur in Texas. Florida rice production occurs during southern Florida's rainy season. Excess water is periodically pumped out of rice fields and may enter adjacent sod farms.

G. graminis var. graminis is an ectotrophic, root-infecting fungus naturally associated with warm-season stoloniferous turfgrasses such as St. Augustinegrass and bermudagrass. These turfgrasses are vegetatively propagated, a practice that helps maintain infected plant material over many harvest cycles. Little information exists on the epidemiology of G. graminis var. graminis $(13,17)$. In rice, the fungus is believed to persist in infected rice debris and perhaps on alternative hosts (17). Other hosts of this fungus include Stenotaphrum and Cynodon spp. $(13,16,17)$.

A few host-range studies have been reported for isolates of $G$. graminis var. graminis $(5,11,14)$, and most research points to little host specificity among isolates of $G$. graminis var. graminis. For example, isolates from grasses readily infect cereal grains $(11,15)$. The purpose of this study was to determine if $G$. graminis var. graminis from rice, St. Augustinegrass, and bermudagrass were cross patho- genic. A partial report on this study was published previously (2).

\section{MATERIALS AND METHODS}

Isolation. If perithecia were present on rice or St. Augustinegrass, they were removed from sheaths or petioles, transferred to a drop of sterile distilled water on a glass microscope slide, and manipulated to induce ascospore release. Ascospore suspensions were placed and then streaked onto $2 \%$ water agar amended with $100 \mu \mathrm{g}$ of streptomycin sulfate per ml. Plates were incubated at $25^{\circ} \mathrm{C}$. After $24 \mathrm{~h}$, germinating single ascospore isolates were removed and placed onto potato dextrose agar (PDA) or water agar amended with $100 \mu \mathrm{g}$ of streptomycin sulfate per $\mathrm{ml}$ for maintenance. Cultures maintained at either room temperature under continuous or diurnal florescent light or in the incubator at $25^{\circ} \mathrm{C}$ under a 12-h photoperiod produced abundant perithecia after 4 to 6 weeks of growth.

Perithecia were never naturally associated with bermudagrass and not always with St. Augustinegrass. Isolates from bermudagrass and St. Augustinegrass, when perithecia were not present, were obtained from infected root or stolon tissue. Tissues were surface disinfested for 30 $\mathrm{s}$ in $1 \%$ silver nitrate solution, rinsed for 30 $\mathrm{s}$ in sterile water, blotted dry on filter paper, and placed either on PDA amended with $100 \mu \mathrm{g}$ of streptomycin sulfate per $\mathrm{ml}$ or on SM-GGT7, a selective medium for Gaeumannomyces-like fungi (5). Isolates were identified initially as G. graminis var. graminis based on the presence of lobed hyphopodia. Confirmation was obtained based on production of fertile perithecia or positive results using a polymerase chain reaction (PCR) assay (6).

Inoculum. Isolates of $G$. graminis var. graminis from Florida included FL173 and FL-221 from rice, FL-39 and FL-104 from St. Augustinegrass, and FL-19 from bermudagrass. Isolates obtained in Texas included TX-91-1 from rice and TX-10466-2 from St. Augustinegrass.

Inoculum of each isolate was prepared by one of two procedures. Inoculum preparation for Florida isolates consisted of mixing $250 \mathrm{ml}$ of whole rye seed with 125 $\mathrm{ml}$ of deionized water in a glass jar. The rye seed was autoclaved twice at $90^{\circ} \mathrm{C}$ for 
90 min on each of 2 consecutive days. For each isolate, one colonized 9-cm PDA plate was chopped into small pieces and mixed with the rye seed. Inoculated rye seed was incubated for 4 weeks at $30^{\circ} \mathrm{C}$. Inoculum for Texas isolates was prepared on rice seed. Seeds were soaked overnight, drained, and ground in a Waring blender for $15 \mathrm{~s}$. A $300-\mathrm{ml}$ sample of the ground seed preparation was placed in a 1-liter Erlenmeyer flask with $100 \mathrm{ml}$ of distilled water and autoclaved at $90^{\circ} \mathrm{C}$ for $60 \mathrm{~min}$. For each isolate, one colonized 9-cm-diameter PDA plate was chopped into small pieces and mixed with rice seed and incu- bated for 4 weeks at room temperature. For all isolates, inoculum was then air-dried and manipulated to break any large aggregates to obtain a uniform texture of about 5 $\mathrm{mm}$ in diameter.

Rice pathogenicity tests in Florida. For each G. graminis var. graminis isolate, soilless growth medium (peat, vermiculite, etc.) was infested with rye inoculum $(5 \%$, $\mathrm{vol} / \mathrm{vol})$ and placed into $2.5 \times 16 \mathrm{~cm}$ tapered plastic containers (Conetainers, Stuewe and Sons, Inc., Corvallis, OR). Rice (cv. Lemont) was seeded into the infested medium and placed in a $28^{\circ} \mathrm{C}$ incubator with a 12-h photoperiod. Con- trols were media mixed with sterile rye seed. There were five replicates per treatment. After 25 days, plants were visually scored for disease development on the lower leaf sheath based on a 0 to 3 rating scale, where $0=$ no disease, $1=1$ to $25 \%$, $2=26$ to $50 \%$, and $3=50$ to $100 \%$ of the lower leaf sheath exhibiting a dark brown to black lesion. Shoot heights and fresh shoot and root weights also were recorded. Infected tissue and tissue from control plants were placed on $2 \%$ water agar containing about 10 to 15 autoclaved rice seeds amended with $100 \mu \mathrm{g}$ of streptomycin sulfate per $\mathrm{ml}$ to reisolate $G$. graminis
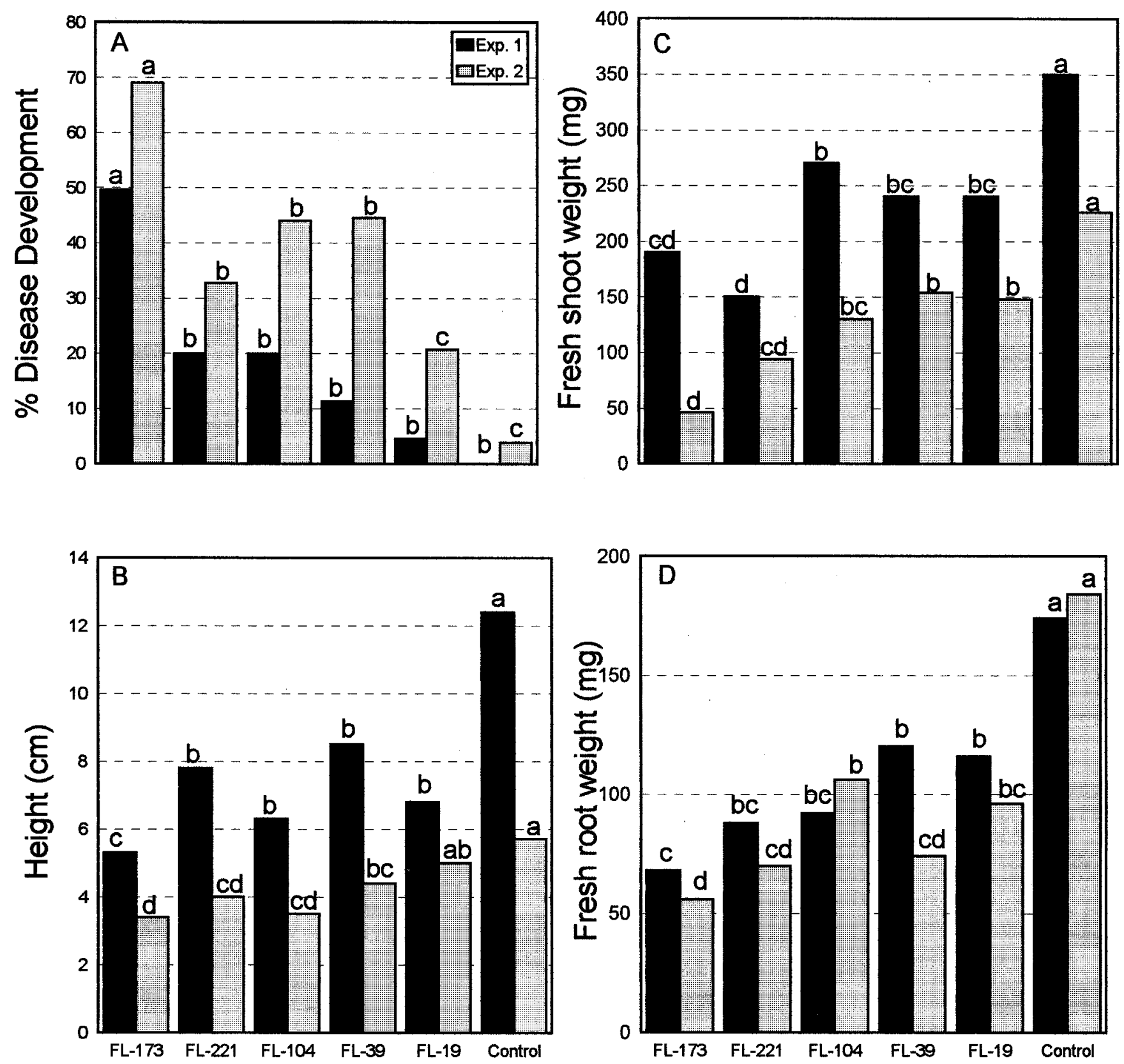

Fig. 1. Effect of Gaeumanomyces graminis var. graminis isolates on black sheath rot development, heights, and shoot and root weight in rice. Percent disease development up the lower leaf sheath was based on a 0 to 3 rating scale, where $0=$ no disease, $1=1$ to $25 \%, 2=26$ to $50 \%$, and $3=50$ to $100 \%$ of the lower leaf sheath exhibiting a dark brown to black lesion. The mean percent disease progress of leaf sheath affected for each numerical rating was used for estimating differences among treatments $(\mathrm{n}=5)$. Means followed by the same letter are not significantly different according to Fisher's least significant difference. Florida isolates of $G$. graminis var. graminis FL-173 and FL-221 were obtained from rice, FL-39 and FL-104 from St. Augustinegrass, and FL19 from bermudagrass. 
var. graminis. The experiment was conducted twice.

Turfgrass pathogenicity tests in Florida. For each $G$. graminis var. graminis isolate evaluated on St. Augustinegrass, a sand:sphagnum peat moss $(80: 20 ; \mathrm{vol} / \mathrm{vol})$ root zone mix was infested with rye inoculum (5\%, vol/vol) and placed in $10 \mathrm{~cm}^{2}$ plastic pots. Controls were amended with sterile rye seed only. There were five replicates per treatment. One sprig of St. Augustinegrass (cv. FX-313) was planted in each pot. Pots were fertilized once, at sprigging, with $2.5 \mathrm{~g}$ of granular fertilizer (Par Ex 16-4-8, Vigoro Industries, Inc., Winter Haven, FL).

For each G. graminis var. graminis isolate evaluated on bermudagrass, the rootzone mix was infested with rye seed inoculum $(5 \%, \mathrm{vol} / \mathrm{vol})$ and placed in $2.5 \times$ $16 \mathrm{~cm}$ tapered plastic containers as previously described. The control treatment was root-zone mix containing sterile rye seed. There were five replicates per treatment. One sprig of hybrid bermudagrass (cv. Tifgreen) was planted in each container. Each plant was fertilized after 3, 4, and 5 weeks growth with quarter-strength Hoagland's solution. Sprigs were obtained by growing the St. Augustinegrass or bermudagrass cultivars in small pots filled with sterile root-zone mix and allowing stolons to grow over the pot edges. This resulted in aerial stolons with roots that did not touch soil and were not infected with the pathogen. This method of producing healthy, diseasefree stolons has been used routinely and successfully in previous experiments.

For each stoloniferous turfgrass species, containers were placed in a randomized complete block design in a greenhouse with ambient temperatures ranging between 25 and $35^{\circ} \mathrm{C}$ and a natural photoperiod during the late spring and summer months. Containers were misted with water for $7 \mathrm{~s}$ every $16 \mathrm{~min}$ during daylight hours. After 10 weeks of growth for the St. Augustinegrass and 6 weeks of growth for the bermudagrass, the experiments were terminated and roots were evaluated for root disease based on the following scale: 1 $=$ no disease; $2=1$ to $25 \%$ of roots with distinct black lesions or a general tan discoloration of the entire root system; $3=26$ to $50 \%$ of roots with black coalescing lesions; $4=51$ to $75 \%$ of roots with black coalescing lesions; $5=76$ to $100 \%$ of roots black. Infected root tissue and root tissue from control plants were placed on SMGGT7 for reisolation of $G$. graminis var. graminis. Each experiment was conducted twice for each turfgrass host.

Turfgrass and rice pathogenicity tests in Texas. Rice inoculum was mixed with a sandy-loam soil $(15 \%, \mathrm{vol} / \mathrm{vol})$, and the mixture was placed in $9 \mathrm{~cm}^{2}$ plastic pots. Single sprigs of St. Augustinegrass (cv. Raleigh) or common bermudagrass, with roots and foliage trimmed uniformly, were transplanted to individual pots. Six rice seeds (cv. Gulfmont) were planted in individual pots. Six single-pot replicates of each host plant were inoculated with either of the two fungal isolates. Six pots of each plant type receiving only ground rice medium served as controls. The plants were arranged in a completely randomized design in a greenhouse for 70 days with an ambient temperature ranging between 25 and $32^{\circ} \mathrm{C}$ and a natural photoperiod during the late spring and summer months. Afterward, plants were evaluated for extent of decay of crowns and leaf sheaths and the presence of perithecia. Plants were rated on a scale of 1 to 5 as previously described for Florida experiments. Reisolation of the pathogen was made using the previously described methods. The experiment was conducted twice.

\section{RESULTS}

Typical dark brown to black lesions, extending upward from the crown, devel- oped on all rice plants, whether inoculated with turfgrass or rice isolates of $G$. graminis var. graminis. Disease development on the lower leaf sheath ranged from approximately 5 to $69 \%$ among all isolates (Fig. 1A). Only rice isolate FL-173 caused significantly greater disease of the lower leaf sheath and root disease severity than other isolates (Fig. 1A). All isolates significantly suppressed shoot and root weights compared with the control (Fig. 1C and D). Only one isolate in one experiment did not significantly lower shoot height compared with the control (Fig. 1B). Although these growth parameters for plants inoculated with the rice isolates FL173 and FL-221 were significantly lower than the control, they were not significantly different for plants inoculated with the St. Augustinegrass or bermudagrass isolates. The pathogen, G. graminis var. graminis, was isolated only from plants grown in infested soil.

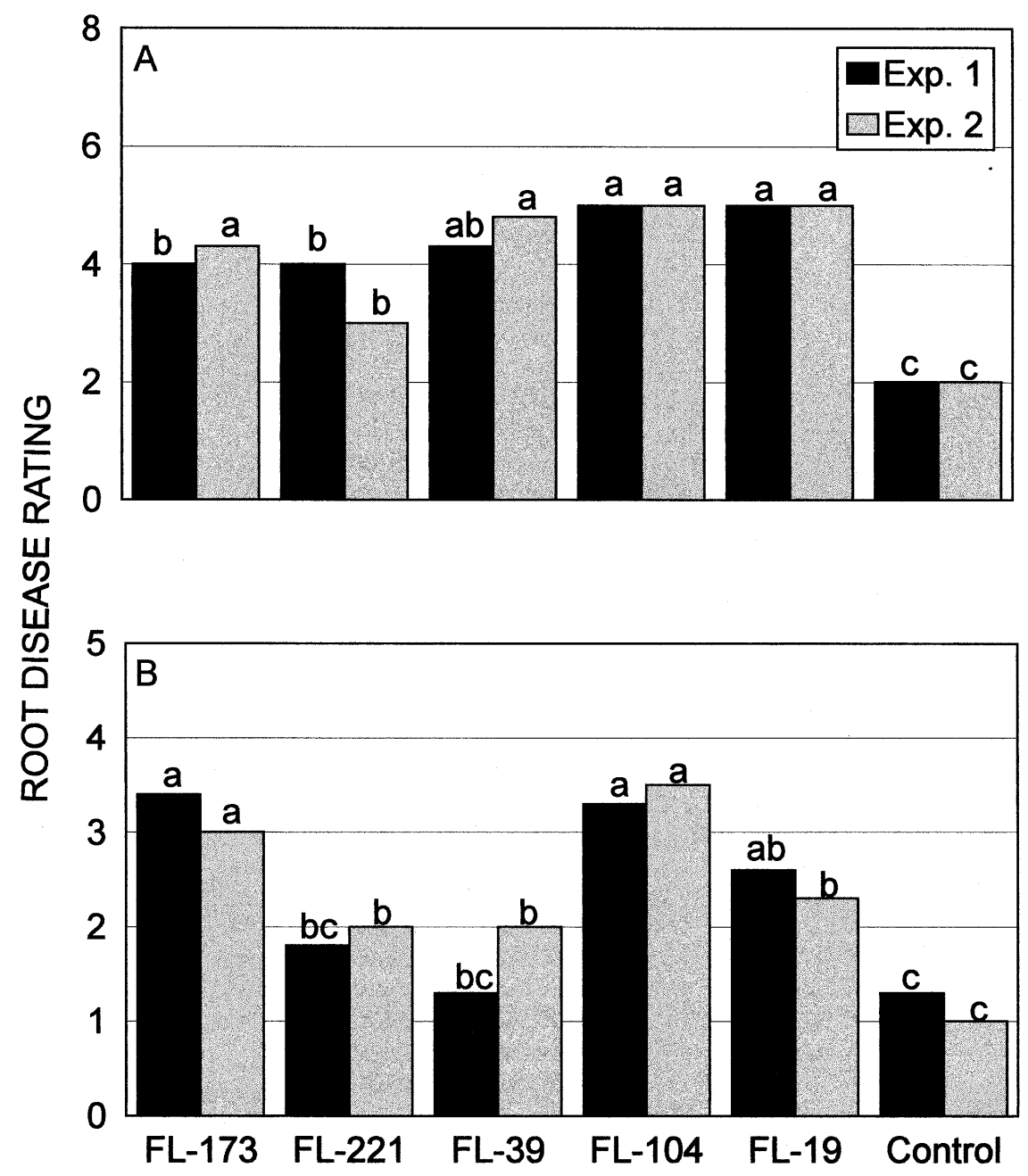

Fig. 2. Effect of Gaeumannomyces graminis var. graminis isolates from Florida on root disease severity of (A) bermudagrass and (B) St. Augustinegrass. Root disease rating was based on the following scale: $1=$ no disease, $2=1$ to $25 \%$ of roots with distinct black lesions or a general tan discoloration of the entire root system, $3=26$ to $50 \%$ of roots with black coalescing lesions, $4=51$ to $75 \%$ of roots with black coalescing lesions, $5=76$ to $100 \%$ of roots black $(n=5)$. Means followed by the same letter are not significantly different according to Fisher's least significant difference. Florida isolates of G. graminis var. graminis FL-173 and FL-221 were obtained from rice, FL-39 and FL-104 from St. Augustinegrass, and FL-19 from bermudagrass. 
All bermudagrass plants grown in the mix infested with $G$. graminis var. graminis isolates resulted in root disease ratings greater than the control (Fig. 2A). In general, the turfgrass isolates were more aggressive than the rice isolates, although the differences were not always significant. The maximum root disease rating of 5 was only associated with bermudagrass isolate FL-19 and St. Augustinegrass isolate FL104. Augustinegrass as the host, rice isolate FL221 and St. Augustinegrass isolate FL-39 had root disease ratings that were not significantly different from the control (Fig. 2B). In the second experiment, all isolates had root disease ratings significantly different from the control. In general, rice isolate FL-173 and St. Augustinegrass isolate FL-104 were significantly more
In the first experiment with St.

aggressive on St. Augustinegrass than were the other isolates. The pathogen, $G$. graminis var. graminis, was only isolated from plants grown in pathogen-infested root-zone mix.

In the Texas pathogenicity test, both the rice isolate (TX-91-1) and the St. Augustinegrass isolate (TX-10466-2) of $G$. graminis var. graminis were pathogenic on St. Augustinegrass, common bermudagrass, and rice (Fig. 3). Symptoms consisted primarily of necrosis of the basal leaf sheaths, root rotting, and discoloration of the stolons and nodes. Perithecia were produced in leaf sheath tissue of St. Augustinegrass inoculated with isolate TX10466-2 and in common bermudagrass, St. Augustinegrass, and rice inoculated with isolate TX-91-1. Both isolates caused similar disease severity on common bermudagrass and St. Augustinegrass, but

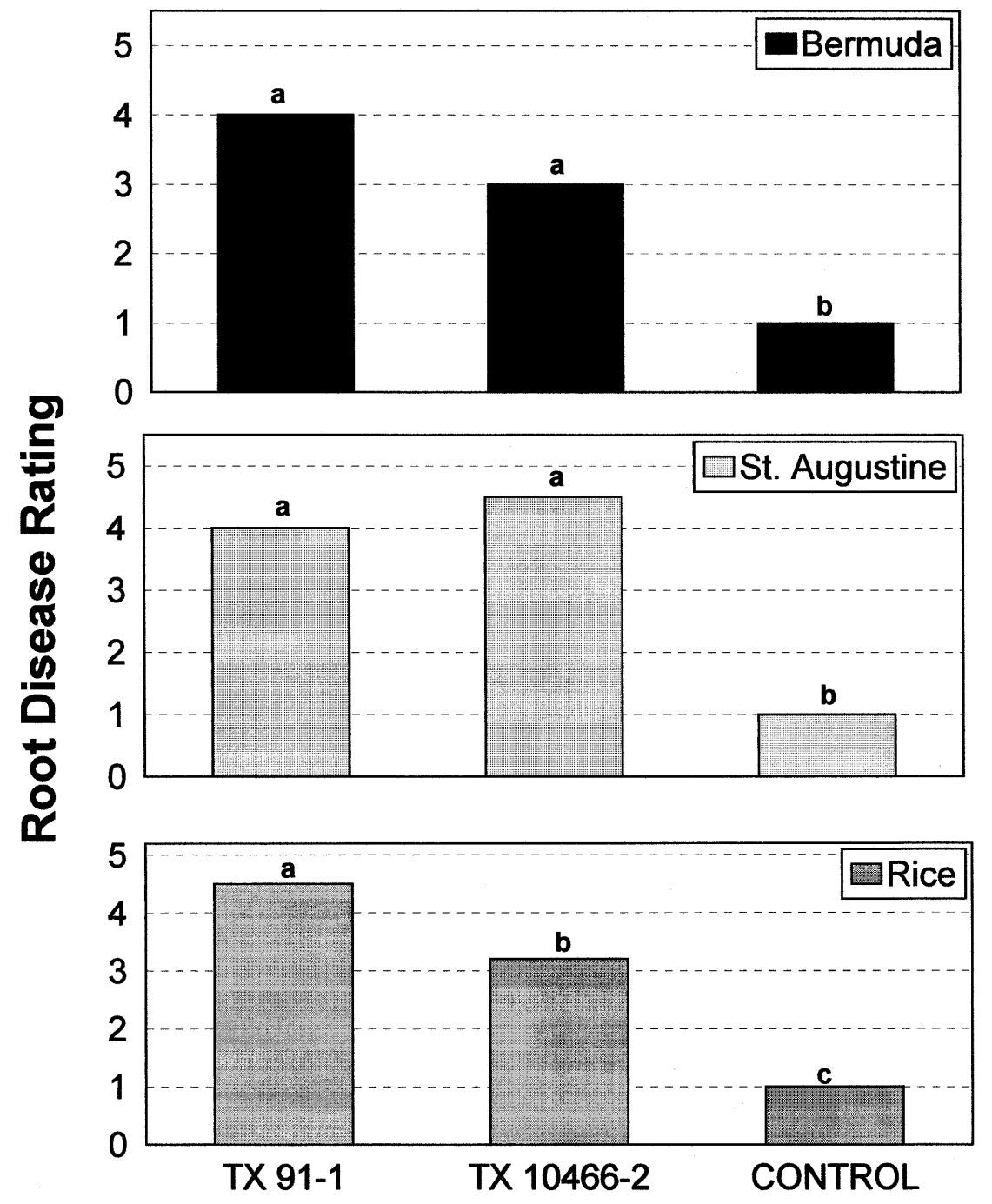

Fig. 3. Effect of Gaeumannomyces graminis var. graminis isolates from Texas on root disease severity in rice, St. Augustinegrass, and bermudagrass. Root disease rating was based on the following scale: $1=$ no disease, $2=1$ to $25 \%$ of roots with distinct black lesions or a general tan discoloration of the entire root system, $3=26$ to $50 \%$ of roots with black coalescing lesions, $4=51$ to $75 \%$ of roots with black coalescing lesions, $5=76$ to $100 \%$ of roots black $(n=6)$. Means followed by the same letter are not significantly different according to Fisher's least significant difference. Texas isolate of G. graminis var. graminis TX91-1 was obtained from rice, and TX10466-2 was obtained from St. Augustinegrass. isolate TX 10466-2 caused less severe disease symptoms on rice than did isolate TX-91-1. Reisolation of G. graminis var. graminis was made only from the infected plants.

\section{DISCUSSION}

Both Florida and Texas isolates of $G$. graminis var. graminis tended to be more aggressive on the host from which they were originally isolated, but the pathogen clearly is not host specific. A study using a PCR assay demonstrated that PCR products produced by isolates from bermudagrass, rice, and St. Augustinegrass correlated with the particular grass host from which the isolates were derived (6). The other $G$. graminis pathogens, var. tritici and var. avenae, have a wide host range on temperate grasses (16). However, only $G$. graminis var. avenae is a pathogen of oats due to its production of the enzyme avenacinase, which detoxifies the oat saponin avenacin A-1. Neither G. graminis var. graminis nor $G$. graminis var. tritici produces this enzyme (12).

Bermudagrass and St. Augustinegrass are perennial turfgrasses that only become dormant if cold temperatures exceed a critical length of time. Generally, environmental conditions in southern Florida do not favor dormancy. Both grasses are grown extensively in urban landscapes as well as in commercial production sites, which provides $G$. graminis var. graminis with live host tissue year-round. Observations in the Netherlands strongly indicated G. graminis var. tritici was spread to newly reclaimed polders by ascospores (8). This should be investigated in Florida and Texas. It is possible that $G$. graminis var. graminis ascospores are moved by wind or water between rice and adjacent turfgrass fields.

\section{LITERATURE CITED}

1. Asher, M. J. C. 1981. Pathogenic variation. Pages 199-218 in: Biology and Control of Take-all. M. J. C. Asher and P. J. Shipton, eds. Academic Press, London.

2. Datnoff, L. E., and Elliott, M. L. 1994. Comparison of grass and rice isolates of Gaeumannomyces graminis var. graminis for pathogenicity and their influence on rice growth and development. Page 94 in: Proc. Rice Tech. Working Group, 25th.

3. Datnoff, L. E., Elliott, M. L., and Jones, D. B. 1993. Black sheath rot caused by Gaeumannomyces graminis var. graminis on rice in Florida. Plant Dis. 77:210.

4. Elliott, M. L. 1991. Determination of an etiological agent of bermudagrass decline. Phytopathology 81:1380-1384.

5. Elliott, M. L. 1991. A selective medium for Gaeumannomyces-like fungi. Plant Dis. 75:1075.

6. Elliott, M. L., Des Jardin, E. A., and Henson, J. M. 1993. Use of a polymerase chain reaction assay to aid in identification of Gaeumannomyces graminis var. graminis from different grass hosts. Phytopathology 83:414418.

7. Elliott, M. L., Hagan, A. K., and Mullen, J. M. 1993. Association of Gaeumannomyces graminis var. graminis with a St. Augustine- 
grass root rot disease. Plant Dis. 77:206-209.

8. Gerlagh, M. 1968. Introduction of Ophiobolus graminis into new polders and its decline. Neth. J. Plant Pathol. 74, Suppl. 2, 97 pp.

9. Krausz, J. P. 1991. Take-all patch suspected in Texas warm-season turf. South. Turf Manage. 2(12): 12 .

10. Krausz, J. P. 1992. Take-all patch increases in Texas turfgrass. Texas Turfgrass 44(4):6-7.

11. Nilsson, H. E., and Drew Smith, J. 1981. Take-all of grasses. Pages 433-448 in: Biology and Control of Take-all. M. J. C. Asher and P. J. Shipton, eds. Academic Press, London.
12. Osbourn, A., Bowyer, P., Lunness, P., Clarke, B., and Daniels, M. 1995. Fungal pathogens of oat roots and tomato leaves employ closely related enzymes to detoxify different host plant saponins. Mol. Plant-Microbe Interact. 8:971-978.

13. Ou, S. H. 1985. Rice Diseases. 2nd ed. Commonw. Mycol. Inst., Kew, England.

14. Roy, K. W., Abney, T. S., Huber, D. M., and Keeler, R. 1982. Isolation of Gaeumannomyces graminis var. graminis from soybeans in the Midwest. Plant Dis. 66:822-825.

15. Skou, J. P. 1981. Morphology and cytology of the infection process. Pages 175-197 in: Biol- ogy and Control of Take-all. M. J. C. Asher and P. J. Shipton, eds. Academic Press, London.

16. Walker, J. 1981. Taxonomy of take-all fungi and related genera and species. Pages 15-74 in: Biology and Control of Take-all. M. J. C. Asher and P. J. Shipton, eds. Academic Press, London.

17. Webster, R. K., and Gunnell, P. S. 1992 Compendium of Rice Diseases. American Phytopathological Society, St. Paul, MN.

18. Whitney, N. G. 1990. Black sheath rot of rice in Texas. Page 76 in: Proc. Rice Tech. Working Group, 23rd. 